\title{
The Intracellular Survival and Growth of Gonococci in Human Phagocytes
}

\author{
By D. R. VEALE, M. GOLDNER*, C. W. PENN, J. WARD \\ AND H. SMITH \\ Department of Microbiology, University of Birmingham, P.O. Box 363, Birmingham B15 2TT
}

(Received 27 November 1978; revised 29 January 1979)

\begin{abstract}
In a reassessment of previous tests for intracellular survival, results have been confirmed and additional evidence obtained indicating that some gonococci can survive and multiply in human phagocytes. Use was made of the ability of penicillin to penetrate phagocytes and to kill only actively growing organisms. In microscopic counts on 33 urethral exudate smears, an average of $49 \%$ of gonococci were associated with polymorphonuclear phagocytes. The organisms were unevenly distributed amongst the phagocytes, with most cells uninfected and some containing large numbers. Many phagocytes also remained uninfected in tests in vitro with low gonococcal inocula although experiments with large inocula showed that most phagocytes could ingest gonococci. It is proposed that ingestion of one gonococcus may stimulate the phagocytes to take up more. Phagocytes were killed and disintegrated after ingesting large numbers of gonococci and a similar effect in vivo may be responsible for the large clumps of organisms seen in urethral exudate. These results underline the probable importance in the pathogenesis of gonorrhoea of intracellular survival in phagocytes.
\end{abstract}

\section{INTRODUCTION}

Electron microscopy of urethral exudate of patients with gonorrhoea reveals that although many gonococci within polymorphonuclear (PMN) phagocytes are disintegrating, others are intact and occasionally appear to be dividing (Farzadegan \& Roth, 1975; Novotny et al., 1975; Ovchinnikov \& Delektorskij, 1977; Ovchinnikov et al., 1976; Ward et al., 1972; our unpublished observations). Similar observations have been made on gonococci phagocytosed in vitro (Ota et al., 1975; Ward et al., 1972; Witt et al., 1976a, b; Walker et al., 1977). In urethral exudate some extracellular gonococci are surrounded by granule-like debris (Novotny et al., 1975, 1977), suggesting that they have been released from damaged phagocytes. Several workers (Novotny et al., 1975, 1977; Ota et al., 1975; Ovchinnikov \& Delektorskij, 1977) have suggested from this electron microscopy that some gonococci survive and grow within phagocytes which may have been damaged by gonococcal attack. It is necessary to establish the reality and scale of this survival to assess its importance in the pathogenesis of gonorrhoea.

Microscopic evidence for intracellular survival cannot overcome the criticism that gonococci which appear intact and dividing may have been recently ingested and are about to be killed. Only counts of intracellular gonococci at different times after phagocytosis in vitro or evidence of active metabolism can establish whether intracellular survival and growth occur. Extracellular bacteria must not interfere with these counts. Thus, a medium for the incubation of infected phagocytes is required which rapidly kills extracellular

* Present address: Department of Microbiology and Parasitology, University of Toronto, Toronto, Ontario, Canada, M5S 1A1. 
organisms but which is not toxic either to intracellular organisms or phagocytes. Such media generally contain antibiotics which often enter phagocytes infected with bacteria (Patterson \& Youmans, 1970; Frost et al., 1972; Cole \& Brostoff, 1975; Veale et al., 1976). Therefore, although intracellular survival may be detected using a concentration of antibiotic which prevents extracellular growth without killing all intracellular organisms (Hart, 1973; Cole \& Brostoff, 1975), the degree of survival may not be as large as would occur in the absence of antibiotics, as in natural infection. Phagocytosis tests in vitro are further complicated by heterogeneity in the resistance of microbial populations to intracellular killing; an early reduction in the more susceptible members may lead to erroneous conclusions that intracellular survival does not occur whereas the resistant organisms may survive and grow if the test is continued.

Investigation of intracellular survival and growth of gonococci has centred on the short-lived PMN phagocytes which predominate in the urethral exudate and in which some gonococcal destruction occurs. When infected with gonococci in vitro, they are penetrated by penicillin when the external concentration reaches or exceeds 0.2 to $0.4 \mu \mathrm{g} \mathrm{ml}^{-1}$ (Veale et al., 1976). Neither Watt (1970) nor Gibbs \& Roberts (1975) detected intraphagocytic survival using higher concentrations of penicillin $\left(1 \mu \mathrm{g} \mathrm{ml}^{-1}\right)$. Thomas et al. (1973), using fresh human serum alone to kill extracellular organisms, detected gonococci for at least $2 \mathrm{~h}$ in human PMN phagocytes. Using $0.4 \mu \mathrm{g}$ penicillin $\mathrm{ml}^{-1}$ in a medium containing $50 \%(\mathrm{v} / \mathrm{v})$ fresh human serum, survival and growth of some gonococci (strain BS) were observed for up to $15 \mathrm{~h}$ in human phagocytes (Veale et al., 1976). Growth of strain BS in subcutaneous chambers in guinea pigs selected organisms with a greater resistance to killing by phagocytes (Witt et al., 1976a). Similarly resistant organisms could be selected in vitro by their "double highlight' (DH) colonial morphology (Penn et al., 1977).

Drutz (1978) used the incorporation of radioactively labelled adenine to indicate intracellular metabolic activity of gonococci in infected human PMN phagocytes treated with rat serum to kill extracellular organisms. However, lack of adenine incorporation by the gonococci may only indicate an absence of nucleic acid synthesis and not necessarily bacterial death. Although it was concluded that there was little survival of a laboratory strain of gonococci in human phagocytes, the measured survival (about $5 \%$ ) over a $3 \mathrm{~h}$ period in PMN phagocytes was similar to that observed by us for strain BS before selection of organisms resistant to phagocytic killing (Veale et al., 1976; Witt et al., 1976a; Penn et al., 1977).

The present study reappraises our previous phagocytosis experiments and provides additional evidence for intracellular growth. In addition, the proportion of gonococci associated with PMN phagocytes in urethral exudate was estimated in order to assess the potential importance of intracellular survival and growth in the pathogenesis of gonorrhoea.

\section{METHODS}

Organisms. The laboratory strain (BSDH) of Neisseria gonorrhoeae was derived, stored and cultured as described previously (Veale et al., 1975; Penn et al., 1977). Urethral exudate from male patients with untreated gonococcal urethritis was collected at the General Hospital, Birmingham, with the help of Dr W. D. Fowler.

Test of intracellular survival. Gonococcal suspensions were prepared as described previously (Witt et al., $1976 b$ ); clumps were dispersed by vigorous mixing (vortex mixer; Hook and Tucker, London) with glass beads for $3 \mathrm{~min}$ and suspensions were pre-incubated $\left(1 \mathrm{~h}, 37^{\circ} \mathrm{C} ; 4 \times 10^{8}\right.$ total organisms $\left.\mathrm{ml}^{-1}\right)$ in the phagocytosis medium. Phagocytes (predominately PMN phagocytes) from human peripheral blood (Witt et al., 1976b) were mixed with gonococci in Leighton tubes at a ratio of $1: 20\left(10^{6}\right.$ phagocytes per tube) in a total volume of $1 \mathrm{ml}$. Control tubes contained no phagocytes. After the $1 \mathrm{~h}$ ingestion period, the deposit of phagocytes and/or gonococci adherent to the flat surface of the Leighton tubes was rapidly washed with three $5 \mathrm{ml}$ volumes of warm $\left(37^{\circ} \mathrm{C}\right)$ medium (Parker medium 199 or Earle's saline) prior to addition of fresh human serum and benzylpenicillin (sodium salt; Glaxo) (Veale et al., 1976). This bactericidal medium remained stable for at least $6 \mathrm{~h}$ at $37^{\circ} \mathrm{C}$. In some experiments, penicillin dissolved in medium $199(0 \cdot 1 \mathrm{ml})$ 
was added after $4 \mathrm{~h}$ incubation to give a final concentration of 17 to $2000 \mu \mathrm{g} \mathrm{ml}^{-1}$. Penicillinase (Riker Laboratories, Loughborough, Leics.; 1000 units in $0.1 \mathrm{ml}$ medium 199) was added to all tubes prior to sampling (Veale et al., 1976); viable and visual counts were made as described previously (Veale et al., 1976; Witt et al., 1976b). Surviving organisms were periodically tested for resistance to penicillin by inoculating

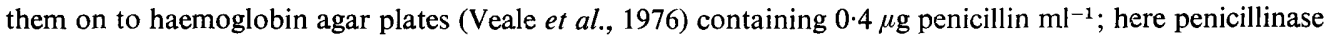
was not added as it could not be completely removed by washing prior to disruption of the deposit of infected phagocytes. Penicillin remaining in suspensions of disrupted phagocyte deposits was assayed by placing $0 \cdot 1 \mathrm{ml}$ of the suspension in a well $(6 \mathrm{~mm}$ diam.) in a haemoglobin agar plate previously spread with a suspension (about $10^{9}$ organisms $\mathrm{ml}^{-1}$ ) of gonococci (strain $\mathrm{BSDH}$ ). After 24 to $48 \mathrm{~h}$ at $37^{\circ} \mathrm{C}$, a zone of growth inhibition around the well indicated the presence of penicillin.

Rigid quantitative assessment of gonococcal survival in these tests is not possible for reasons which have been stated previousily (Witt et al., 1976b). However, the tests can indicate whether or not intracellular survival and growth occur (Veale et al., 1976, 1978; Witt et al., 1976a, b; Penn et al., 1977).

Counts of extracellular and intracellular gonococci in urethral exudate. Samples from 33 male patients with acute gonococcal urethritis were examined. Two were provided by P. Novotny (Wellcome Research Laboratories, Beckenham, Kent) and the rest were from the General Hospital, Birmingham. The smears, which had been Gram-stained for diagnostic purposes, were counterstained with Giemsa stain (Witt et al., $1976 b$ ) to enhance the appearance of the host cells. Determinations were made of (i) the percentage of PMN phagocytes in the total cell population (average 410 PMN phagocytes counted per smear), (ii) the percentage of PMN and epithelial cells with associated gonococci (averages of 400 PMN phagocytes and 25 epithelial cells counted per smear) and (iii) the number of gonococci associated with infected PMN and epithelial cells (about 50 PMN and 25 epithelial cells counted per smear). These determinations were made both in the body and at the edges of the smear.

Estimates were also made of the proportions of gonococci in the smears that were (i) extracellular (i.e. not cell-associated), (ii) associated with PMN phagocytes and (iii) associated with epithelial cells. A total of 30920 organisms was counted [average 937 organisms per smear, standard error \pm 63 ]. These bacterial counts were made at the edges of the smears where $<50 \%$ of the area was occupied by host cells, thus facilitating the distinction of extra- and intracellular organisms.

\section{RESULTS}

\section{Survival of gonococci in human phagocytes using fresh human serum and penicillin as external bactericidal agents}

The results summarized in Table 1 are similar to those reported previously (Veale et al., 1976; Witt et al., 1976 a, b). Penicillin concentrations of $0 \cdot 4 \mu \mathrm{g} \mathrm{ml}^{-1}$ or greater (in conjunction with fresh human serum) efficiently killed extracellular organisms. The number of cellassociated organisms detected in the deposits usually decreased with increasing penicillin concentration. Substantial survival was observed after 4 and $6 \mathrm{~h}$ incubation, particularly with $0.4 \mu \mathrm{g}$ penicillin $\mathrm{ml}^{-1}$.

In some experiments (Tables 2, expts 1,2 and 3), there was a marked decline in viable intracellular gonococci at $6 \mathrm{~h}$ when extra penicillin had been added at $4 \mathrm{~h}$. Similar results were obtained in four other experiments. However, in some experiments (Table 2, expts 4 and 5), the addition of penicillin at $4 \mathrm{~h}$ had little effect on subsequent intracellular survival. Substantial deposit counts were obtained even in the presence of high external concentrations (170 to $200 \mu \mathrm{g} \mathrm{ml}^{-1}$ ) of antibiotic. Similar results were obtained in six other experiments. The $\mathrm{pH}$ of the medium at 4 and $6 \mathrm{~h}$ was slightly acid (about $\mathrm{pH} \mathrm{6.5)} \mathrm{in} \mathrm{experiments} \mathrm{where}$ the addition of extra penicillin had little effect on deposit counts, whereas more variation in $\mathrm{pH}$ (usually neutral to slightly alkaline) occurred in experiments where extra penicillin reduced the deposit count. Surviving organisms of intracellular origin did not appear to be markedly resistant to penicillin: in three experiments, after release from the deposits, they did not grow on solid media containing $0.4 \mu \mathrm{g}$ penicillin $\mathrm{ml}^{-1}$.

Further evidence for the intracellular location of gonococci persisting in deposits after 4 and $6 \mathrm{~h}$ incubation was obtained (Table 3, expts 1 to 4 ): the infected phagocytes in some deposits were disrupted at $4 \mathrm{~h}$, by scraping them off the glass with a rubber-tipped glass rod and mixing, and then incubated with 0 to $200 \mu \mathrm{g}$ penicillin $\mathrm{ml}^{-1}$ in the presence of fresh human serum. No survival was detected in these tubes at $6 \mathrm{~h}$, in contrast to the 


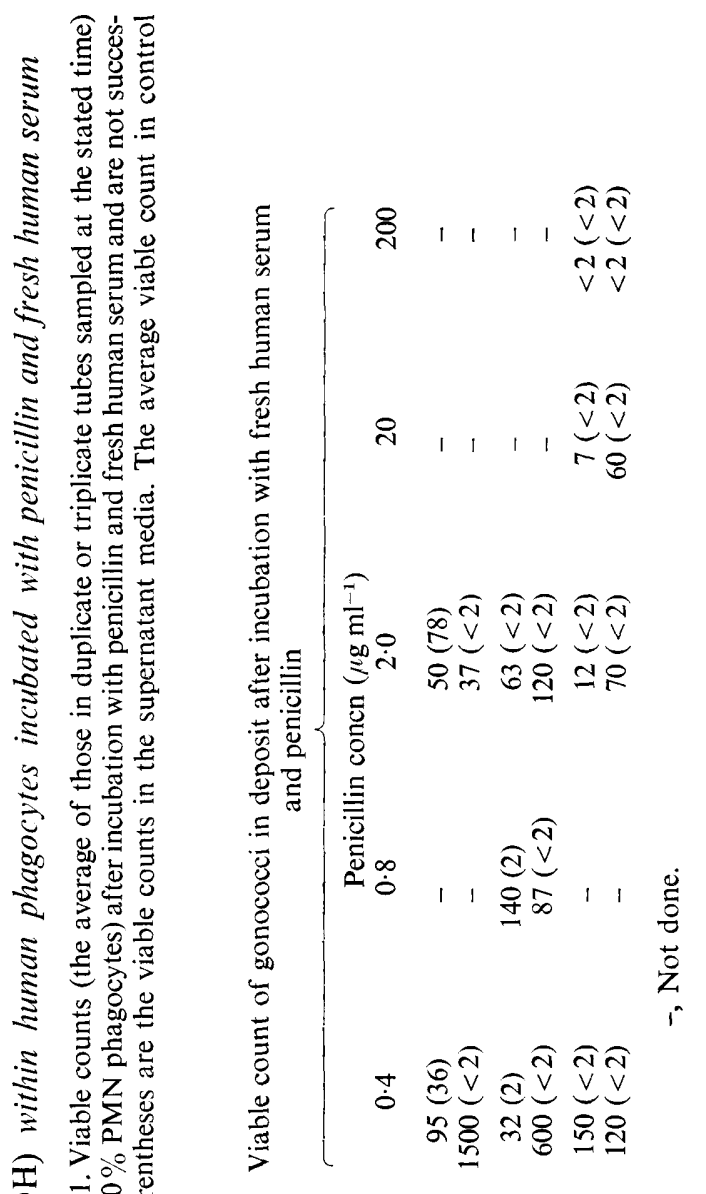

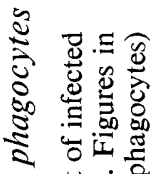

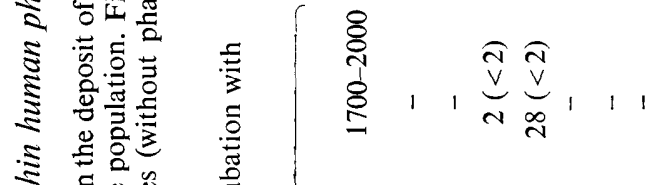

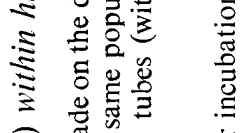

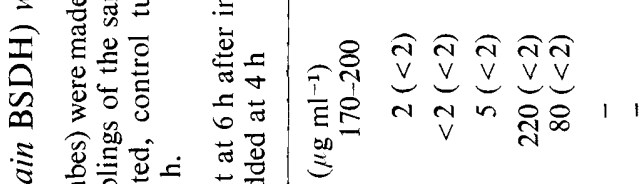

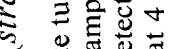

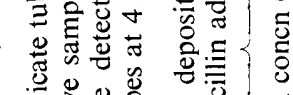

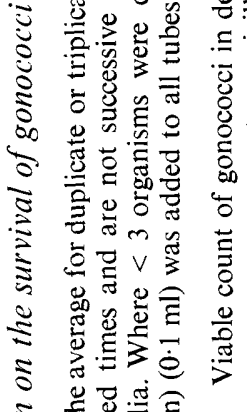

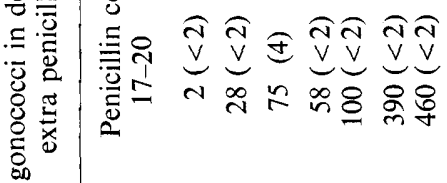

至

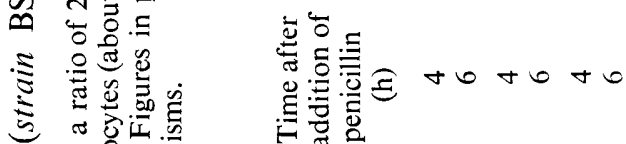

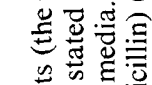

言焉范

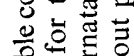

>. 돌

通苛范

苍.

월

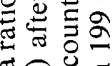

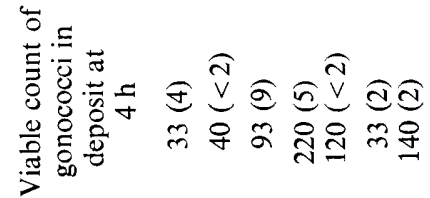

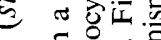
吾

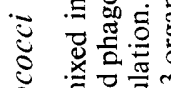

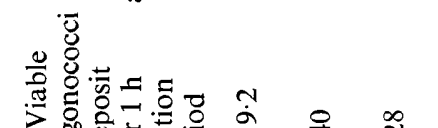

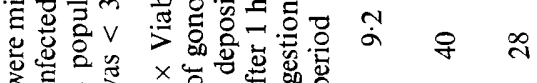

$\infty \begin{aligned} & \infty \\ & \infty\end{aligned}$

จ

志

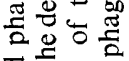

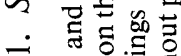

․

无

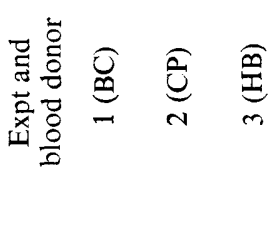

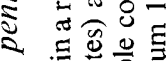

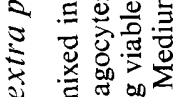

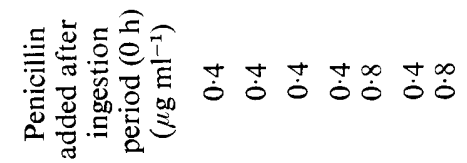

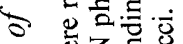

.

矛 800

○

远芯芯芯

讨

용요

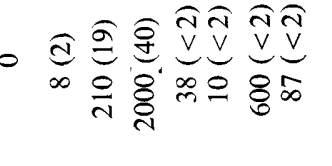
$\dot{0}$
$\stackrel{\tilde{g}}{0}$
$\overrightarrow{0}$
$z$

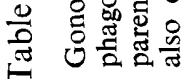




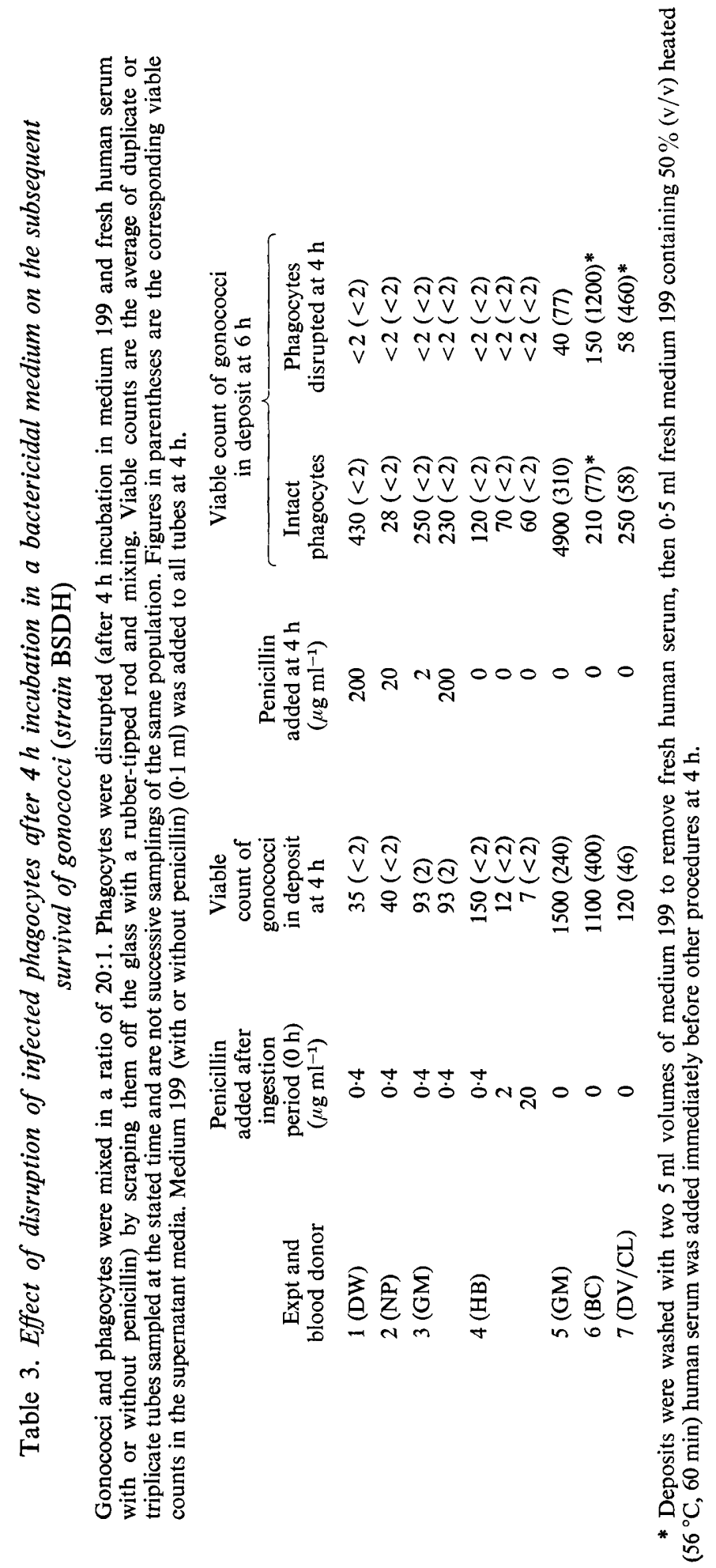


Table 4. Distribution of extracellular and cell-associated gonococci in urethral exudates

Counts were made of 33 smears of urethral exudates (see Methods). Average values are given \pm standard errors. Host calls in urethral exudates were $94.1 \%$ PMN phagocytes (standard error \pm 2.0 ); the remainder were epithelial and monocytic cells in approximately equal proportions. Occasionally small numbers of gonococci were seen associated with monocytic cells.

$\begin{array}{lccc}\text { Extracellular } & & \text { Cell-associated gonococci } \\ \begin{array}{c}\text { Percentage of gonococci } \\ \text { in stated site }\end{array} & 35 \cdot 1 \pm 3 \cdot 6 & 15 \cdot 7 \pm 3 \cdot 1 & 49 \cdot 2 \pm 4 \cdot 4 \\ \begin{array}{c}\text { Pencentage of cells with } \\ \text { associated gonococci }\end{array} & & 64 \cdot 7 \pm 5 \cdot 5 & 7 \cdot 2 \pm 1 \cdot 0 \\ \begin{array}{c}\text { Average no. of gonococci } \\ \text { per infected cell }\end{array} & & 21 \cdot 5 \pm 1 \cdot 7 & 14 \cdot 7 \pm 1 \cdot 1\end{array}$

substantial numbers of deposit organisms in tubes containing undisturbed, intact phagocytes. The killing of organisms released from disrupted phagocytes appeared to be due to the penicillin and fresh human serum in the medium rather than to release of bactericidins from the phagocytes. In separate experiments some killing occurred after infected phagocytes were disrupted in the absence of penicillin but in the presence of fresh human serum (Table 3, expt 5). On the other hand, substantial survival was seen when the cells were disrupted in a medium lacking penicillin but containing heated serum (Table 3, expts 6 and 7).

\section{Distribution of extracellular and cell-associated gonococci in urethral exudates}

In urethral smears, gonococci were either extracellular or associated with PMN phagocytes (the predominant cell type) or epithelial cells (Table 4). Only occasionally were single organisms or small groups seen associated with monocytic cells. About $35 \%$ of the total gonococci were extracellular. They were seen singly, as diplococci and in clumps (some of which contained $>100$ organisms). Some smears contained many large clumps while others had few containing $>5$ organisms. Large clumps were sometimes seen adjacent to damaged PMN phagocytes and some contained purple-stained debris which could have been of host cell origin (see Novotny et al., 1975, 1977).

The majority $(65 \%)$ of epithelial cells had bacteria (about $16 \%$ of the total) associated with them. There were approximately 22 gonococci per infected epithelial cell. Usually these organisms were not distributed randomly but were concentrated in patches, those in a particular patch appearing to be in the same optical plane but different patches on the same cell were often in different planes. In a small proportion $(3 \%)$ of infected cells, gonococci were in regularly spaced arrays of $>8$ organisms suggestive of cell division.

On average, $49 \%$ of the total gonococci in the sample were associated with PMN phagocytes, but there were considerable differences between smears (range 4 to $90 \%$ ). The distribution of gonococci in PMN phagocytes was different from that in epithelial cells. Only a small proportion (average $7 \%$ ) of PMN phagocytes contained gonococci which appeared randomly distributed throughout the cell. Infected PMN phagocytes contained about 15 organisms but sometimes large numbers $(50$ to $>100)$ were seen associated with a single cell. In three samples, differing widely in the proportion of gonococci associated with PMN phagocytes, the distribution of organisms was similar (Fig. 1).

\section{Distribution of cell-associated gonococci after phagocytosis of different gonococial inocula in vitro}

Figure 2 shows the frequency distribution for strain BSDH grown in vitro within human blood leukocytes after a $1 \mathrm{~h}$ ingestion period in Leighton tubes for three different ratios of gonococci to phagocytes. Previous electron microscopic observations (Penn et al., 1977) indicated that the majority of these cell-associated organisms were intracellular. At the 

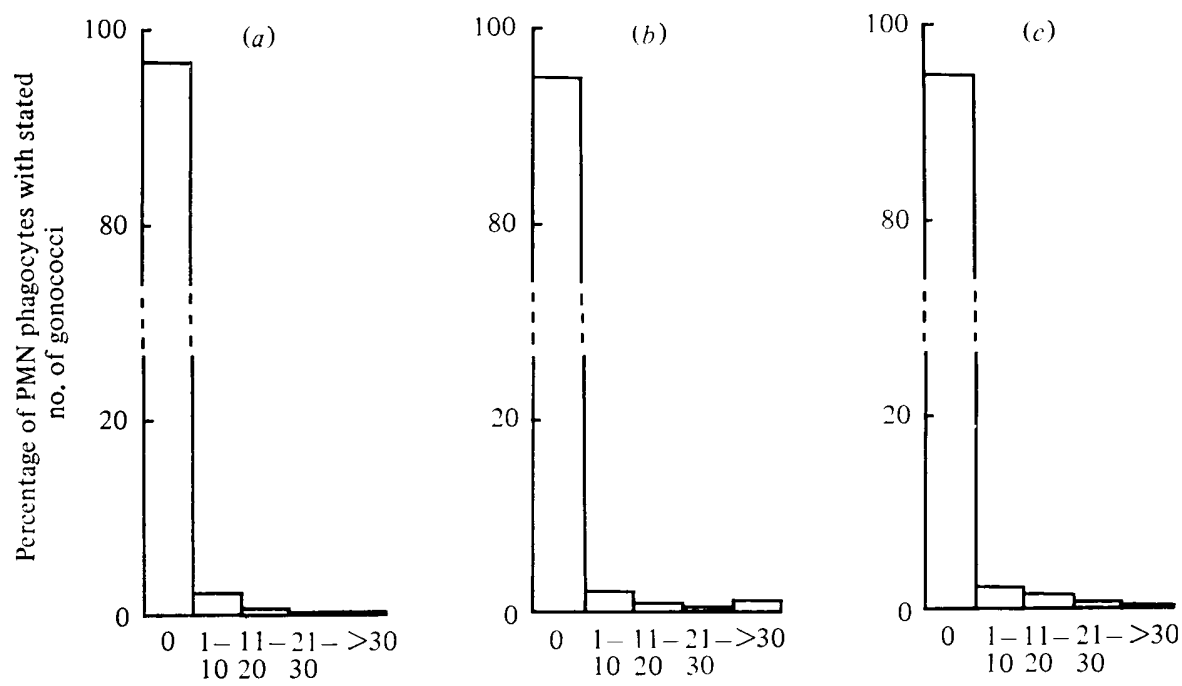

No. of gonococci per PMN phagocyte

Fig. 1. Distribution of gonocccci among the PMN phagocytes of three samples of urethral exudate having different proportions of cell-associated organisms: (a) $4 \%$ of total gonococci PMNassociated (average 10 gonococci per infected phagocyte);(b) $49 \%$ of total gonococci PMN-associated (average 20 gonococci per infected phagocyte); (c) $90 \%$ of total gonococci PMN-associated (average 14 gonococci per infected phagocyte).
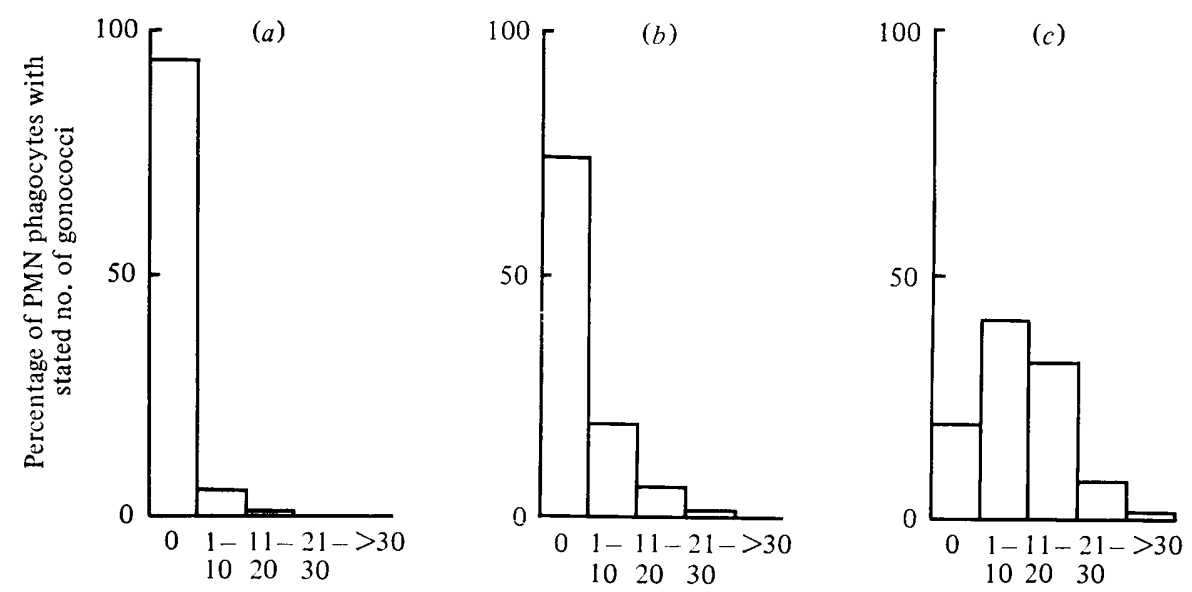

No. of gonococci per PMN phagocyte

Fig. 2. Distribution of cell-associated $N$. gonorrhoeae (strain BSDH) among PMN phagocytes $\left(10^{6} \mathrm{ml}^{-1}\right)$ of human blood after a $1 \mathrm{~h}$ ingestion period in vitro: $(a)$ inoculum, 1 gonococcus per PMN phagocyte (average 6 gonococci per infected phagocyte); (b) inoculum, 10 gonococci per PMN phagocyte (average 8 gonococci per infected phagocyte); (c) inoculum, 100 gonococci per PMN phagocyte (average 11 gonococci per infected phagocyte). Numbers of gonococci in inocula were estimated from total counts.

lowest ratio, the distribution of gonococci within the phagocytes resembled that observed for gonococci in smears of urethral exudates (Fig. 1) although there were fewer phagocytes with large numbers of associated organisms. As the ratio was increased the proportion of phagocytes containing gonococci also rose until the majority of phagocytes were infected. Similar results were obtained in two other experiments. 


\section{Table 5. Toxic effect on phagocytes of very high gonococcal inocula}

Initially, $1 \times 10^{6}$ phagocytes were added to each tube. Counts (the average for duplicate or triplicate tubes) were made on visually intact phagocytes (about $80 \%$ PMN phagocytes).

Microscopic counts after incubation of phagocytes with gonococci for $60 \mathrm{~min}$

$\begin{array}{cccc}\begin{array}{c}\text { Expt and } \\ \text { blood donor }\end{array} & \begin{array}{c}\text { Ratio of gonococci* } \\ \text { to phagocytes }\end{array} & \begin{array}{c}10^{-4} \times \text { Average no. of } \\ \text { phagocytes at tached } \\ \text { to glass }\end{array} & \begin{array}{c}\text { Gonococci } \\ \text { infected pha }\end{array} \\ 1(\mathrm{HL}) & 5: 1 & 6 \cdot 9 & 6 \\ & 50: 1 & 16 \cdot 5 & 26 \\ 2(\mathrm{TK}) & 500: 1 & <0 \cdot 1 & \text { TF } \\ & 100: 1 & 4 \cdot 2 & 6 \\ 3(\mathrm{JM}) & 500: 1 & 5 \cdot 9 & 12 \\ & 2500: 1 & <0 \cdot 1 \dagger & 7 \\ & 100: 1 & 8 \cdot 7 & 7 \\ & 500: 1 & 0 \cdot 44 \dagger & 22\end{array}$

TF, Too few intact cells to count.

* Estimated from total count.

$\dagger$ Many damaged and lysed PMN phagocytes which had ingested large numbers of gonococci were present.
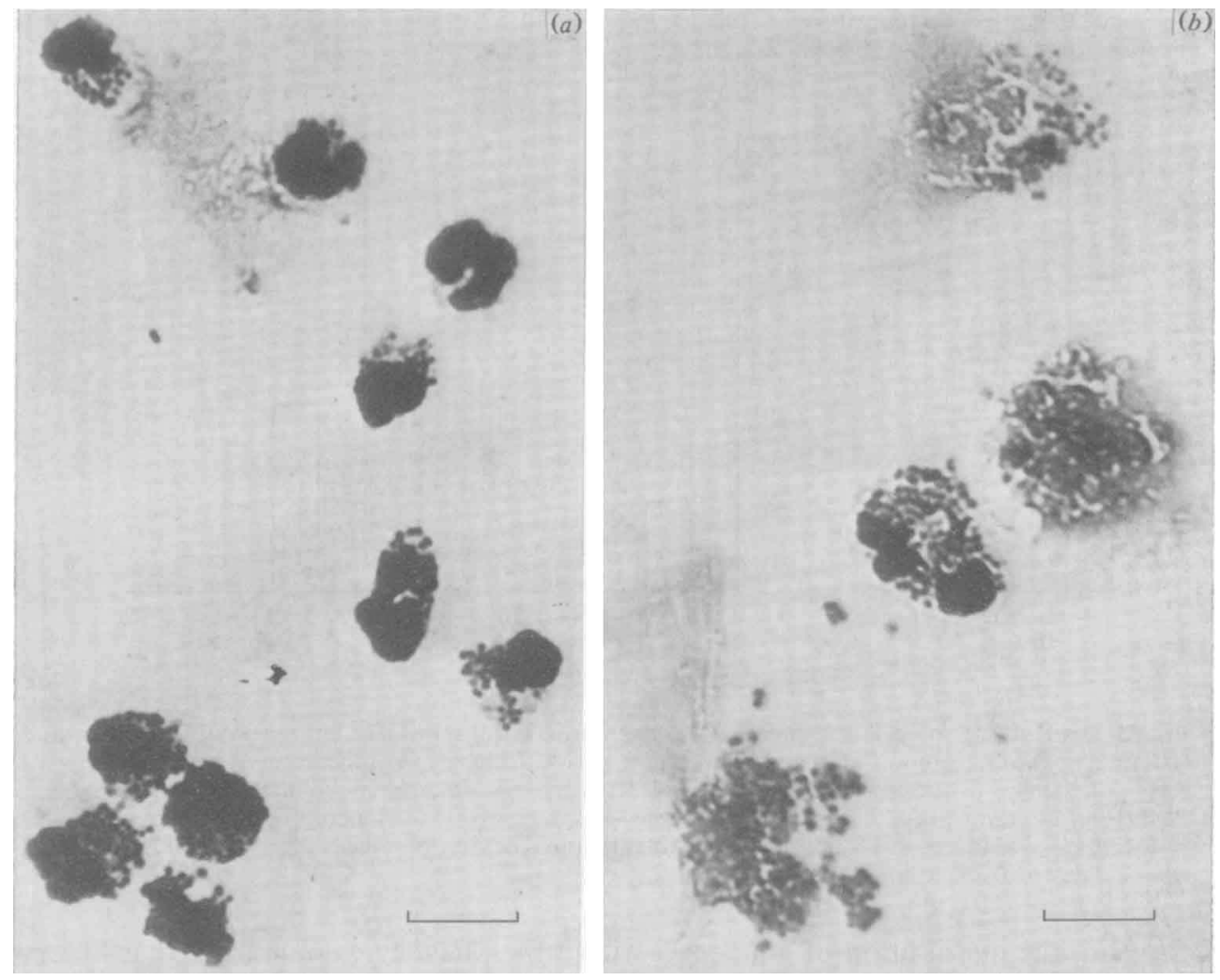

Fig. 3. Appearance of Giemsa-stained PMN phagocytes after $1 \mathrm{~h}$ incubation with $N$. gonorrhoeae (strain BSDH). (a) Inoculum, 50 gonococci per PMN phagocyte: intact PMN phagocytes with many associated organisms. (b) Inoculum, 500 gonococci per PMN phagocyte: damaged and lysed PMN phagocytes. Bar markers represent $20 \mu \mathrm{m}$. 


\section{Toxic effects on phagocytes of large numbers of ingested organisms}

In three experiments, gonococci were incubated with phagocytes $\left(10^{6}\right.$ per tube) for $60 \mathrm{~min}$ at different gonococci to phagocyte ratios $(5: 1$ to $2500: 1)$. The higher concentrations of gonococci had a toxic effect on the phagocytes. The number of intact phagocytes adhering to the glass after the ingestion period was less than for the lower inocula (Table 5) and many damaged phagocytes were seen with large numbers of associated organisms. Clumps of gonococci were also seen surrounded by the faintly stained debris of phagocytes; this was not observed at lower ratios of gonococci to phagocytes (Table 5, Fig. 3).

\section{DISCUSSION}

This paper confirms and extends the evidence for intracellular survival and growth of gonococci presented previously (Veale et al., 1976; Witt et al., 1976a,b).

Abortive attempts were made to use rat serum as an external bactericidal agent (Drutz, 1978 ) in our tests, in which viable counts were the criteria of survival and growth. Two batches of rat serum caused phagocytes to detach from glass and did not completely kill extracellular organisms. Assessment of intracellular bacterial counts was therefore difficult but in several tests gonococci appeared to survive for 4 to $6 \mathrm{~h}$ in the few phagocytes that remained attached to the glass.

Using penicillin and fresh human serum as external bactericidal agents, the results of the tests in Table 1 are similar to those published previously in which electron microscopy had shown the intracellular location of the gonococci (Veale et al., 1976; Witt et al., 1976a, b). At that time we had not realized that the killing of intracellular gonococci by the higher penicillin concentrations is, in itself, evidence of intracellular gonococcal growth. This conclusion is made on the reasonable assumption that gonococci, like other bacteria, are susceptible to penicillin only when growing (Ghuysen, 1977).

In this paper we provide additional evidence that gonococci persisting in the phagocyte deposits at $4 \mathrm{~h}$ in the presence of a small amount of penicillin were both growing and intracellular. Growth was also shown by the fact that addition of more penicillin at $4 \mathrm{~h}$ reduced the survival of gonococci detected in the undisturbed phagocyte deposits at $6 \mathrm{~h}$ (Table 2, expts 1, 2 and 3). Intracellular habitat was indicated by complete elimination of the gonococci when the phagocytes were disrupted into the bactericidal medium containing penicillin and fresh human serum (Table 3). The survival of intracellular gonococci in some experiments at high concentrations of penicillin added at $4 \mathrm{~h}$ (Table 2, expts 4,5 ) was not due to penicillin resistance of the bacteria since survivors were no more resistant than the original population. Under some circumstances, phagocytes may either acquire or retain an impermeability to penicillin. The lowered $\mathrm{pH}$ (about 6.5) of the medium noted in these experiments may have reflected a more active glycolytic metabolism of the phagocytes.

In urethral exudate more than $50 \%$ of the gonococci were seen in association with either PMN cells or epithelial cells (Table 4). Similar results were reported by King et al. (1978). The arrangement of gonococci associated with epithelial cells suggested that most of the bacteria were attached to the cell surface (see Ward \& Watt, 1972; Ward et al., 1975). In contrast, electron microscopy (Ovchinnikov et al., 1976; Ovchinnikov \& Delektorskij, 1977; Ward et al., 1972; our unpublished observations) indicated that the majority of gonococci associated with PMN phagocytes are intracellular. These substantial numbers of urogenital tract gonococci with an intracellular habitat and a capacity to survive and grow could play a major role in the pathogenesis of gonorrhoea.

Different samples of exudate varied with respect to the percentage of gonococci associated with PMN phagocytes (4 to $90 \%$ ), a finding similar to that of King et al. (1978). This variation may reflect differences in stages of infection, the efficiency of the patients' phagocytes, or the ability of different gonococcal strains to associate with them and to persist intracellularly. 
In urethral pus, many phagocytes did not contain gonococci and a few had large numbers (Fig. 1). Innate heterogeneity of phagocyte function was partially responsible for this distribution; however, experiments in vitro (Fig. $2 c$ ) indicated that most phagocytes could ingest gonococci providing that the concentration of bacteria was high. With low concentrations of gonococci only a few of the phagocytes contained bacteria (usually more than one; Fig. $2 a$ ) which was similar to the situation in urethral pus. However, a difference was also apparent as the large numbers $(>20)$ of gonococci seen in individual urethral exudate phagocytes (Fig. 1) were not found in vitro (Fig. 2a) unless the inoculum was high (Fig. 2b, c). The most plausible explanation for the uneven distribution seen in vivo and in vitro in tests with small inocula is that ingestion of one or two gonococci induces phagocytes to ingest additional organisms more efficiently than uninfected phagocytes. It may be relevant that phagocytes that have ingested gonococci adhere to glass better than uninfected cells (Veale et al., 1976). Recent migration of uninfected cells into the pus may also influence the situation in vivo. The very large numbers of organisms seen in some phagocytes in urethral pus do not appear to have arisen from ingestion of large clumps of extracellular organisms because the distribution of gonococci among the phagocytes was similar whether the smears contained many clumps of extracellular organisms or few. The large numbers may arise from intracellular multiplication or even through phagocytosis of moribund heavily infected cells, although phagocyte debris has not been noticed within healthy PMN phagocytes containing gonococci.

Phagocytes died and disintegrated after ingesting many gonococci (Table 5, Fig. 3). Release of intracellular organisms by a toxic effect on the phagocytes may explain the large clumps of extracellular gonococci seen in some urethral exudates. In less heavily infected cells, the toxic effect might facilitate intracellular growth of gonococci and induce the permeability of phagocytes to penicillin.

We thank Mrs S. Atkins, Mrs J. Lichfield, Mr K. Witt and our blood donors for valuable assistance. This work was supported by the Medical Research Council.

\section{REFERENCES}

Cole, J. \& Brostoff, J. (1975). Intracellular killing of Listeria monocytogenes by activated macrophages (Mackaness system) is due to antibiotic. Nature, London 256, 515-517.

Drutz, D. J. (1978). The intracellular fate of Neisseria gonorrhoece. In Immunobiology of Neisseria gonorrhoeae, pp. 232-235. Edited by G. F. Brooks, E. C. Gotshlich, K. K. Holmes, W. D. Sawyer \& F. E. Young. Washington, D.C.: American Society for Microbiology.

Farzadegan, H. \& Roth, I. L. (1975). Scanning electron microscopy and freeze etching of gonorrhoeal urethral exudate. British Journal of Venerecil Disease 51, 83-91.

Frost, A. J., Smith, H., Witt, K. \& Keppie, J. (1972). The chemical basis of the virulence of Brucella abortus. X. A surface virulence factor which facilitates intracellular growth of Brucella abortus in bovine phagocytes. British Journal of Experimental Pathology 53, 587-596.

GHUYSEN, J. M. (1977). In The Bacterial DDCarboxypeptidase-Transpeptidase System. A New Insight into the Action of Penicillin, p. 32. Tokyo: University of Tokyo Press.

Gibis, D. L. \& Roberts, R. B. (1975). The interaction in vitro between human polymorphonuclear leukocytes and Neisseria gonorrhoeae cultivated in the chick embryo. Journal of Experimental Medicine 141, 155-171.

HART, P. D'ARCy (1973). Critical approach to the technique of assessment of antibacterial effects of activated mouse peritoneal macrophages. Excerpta Medica International Congress of Serology 325, 131-137.

King, G., James, J. F. \& Swanson, J. (1978). Studies on gonococcus infection. XI. Comparison of in vivo and in vitro association of Neisseria gonorrhoeae with human neutrophils. Journal of Infectious Diseases 137, 38-43.

Novotny, P., Short, J. A. \& Walker, P. D. (1975). An electron microscope study of naturally occurring and cultured cells of Neisseria gonorrhoeae. Journal of Medical Microbiology 8, 413-427.

Novotny, P., Short, J. A., Hughes, M., Miler, J. J., Syrett, C., Turner, W. H., Harris, J. R. W \& MaCClennan, I. P. B. (1977). Studies on the mechanism of pathogenicity of Neisseria gonorrhoeae. Journal of Medical Microbiology 10, 347368.

Ota, F., Morita, J., Yoshida, N., Ashton, F. \& DienA, B. (1975). Studies on gonococcal infection. I. Electron microscopic studies on phagocytosis of Neisseria gonorrhoeae by macrophages. Japanese Journal of Microbiology 19. 149-155. 
Ovchinnikov, N. M. \& DelektorskiJ, V. V. (1977). Phagocytosis in urethral discharge from patients with gonorrhoea. In Gonorrhoea: Epidemiology and Pathogenesis, FEMS Symposium no. 2, pp. 157-183. Edited by F. A. Skinner, P. D. Walker \& H. Smith. London: Academic Press.

Ovchinnikov, N. M., DelektorskiJ, V. V. \& Dmitriev, G. A. (1976). Ultrastructure of gonococci in acute, chronic and asymptomatic gonorrhoea. British Journal of Venereal Disease 52, 230-245.

Patterson, R. N. \& Youmans, G. P. (1970). Multiplication of Mycobacterium tuberculosis within normal and 'immune' mouse macrophages cultivated with and without streptomycin. Infection and Immunity 1, 30-40.

Penn, C. W., Veale, D. R. \& Smith, H. (1977). Selection from gonococci grown in vitro of a colony type with some virulence properties of organisms adapted in vivo. Journal of General Microbiology 100, 147-158.

Thomas, D. W., Hill, J. C. \& Tyeryar, F. J., JR (1973). Interaction of gonococci with phagocytic cells from men and mice. Infection and Immunity $\mathbf{8}$, 98-104.

Veale, D. R., Smith, H., Witt, K. \& Marshall, R. B. (1975). Differential ability of colonial types of Neisseria gonorrhoeae to produce infection and an inflammatory response in subcutaneous perforated plastic chambers in guinea pigs and rabbits. Journal of Medical Microbiology 8, 325335.

Veale, D. R., Finch, H., Smith, H. \& Witt, K. (1976). Penetration of penicillin into human phagocytes containing Neisseria gonorrhoeae: intracellular survival and growth at optimum concentrations of antibiotic. Journal of General Microbiology 95, 353-363.
Veale, D. R., Penn, C. W., Sutton, S. \& Smith, H. (1978). The effect of specific antiserum on the resistance of Neisseria gonorrhoeae to intracellular killing by phagocytes of human blood. Journal of General Microbiology 106, 129-136.

Walker, P. D., Hine, P., MacCormic, C. \& Miler, J. (1977). Gonorrhoea: prospects for immunity. In Gonorrhoea: Epidemiology and Pathogenesis, FEMS Symposium no. 2, pp. 207-229. Edited by F. A. Skinner, P. D. Walker \& H. Smith. London: Academic Press.

WARD, M. E. \& WATt, P. J. (1972). Adherence of Neisseria gonorrhoeae to urethral mucosal cells: an electron-microscopic study of human gonorrhoea. Journal of Infectious Diseases 126, 601-605.

Ward, M. E., GlynN, A. A. \& WatT, P. J. (1972). The fate of gonococci in polymorphonuclear leukocytes: an electronmicroscopic study of the natural disease. British Journal of Experimental Pathology 53, 289-294.

WARd. M. E., Robertson, J. N., ENGLEFiEld, P. M. \& WATT, P. J. (1975). Gonococcal infection: invasion of the mucosal surfaces of the genital tract. In Microbiology-1975, pp. 188-199. Edited by D. Schlessinger. Washington, D.C.: American Society for Microbiology.

WATt, P. J. (1970). The fate of gonococci in polymorphonuclear leucocytes. Journal of Medical Microbiology 3, 501-509.

Witt, K., Veale, D. R., Finch, H., Penn, C. W., SEN, D. \& SMith, H. (1976a). Resistance of Neisseria gonorrhoeae grown in vivo to ingestion and digestion by phagocytes of human blood. Journal of General Microbiology 96, 341-350.

Witt, K., Veale, D. R. \& Smith, H. (1976b). Resistance of Neisseria gonorrhoeae to ingestion and digestion by phagocytes of human buffy coat. Journal of Medical Microbiology 9, 1-12. 